\title{
Characteristics of textile and clothing sector social entrepreneurs in the transition to the circular economy
}

DOI: $10.35530 / I T .072 .01 .202031$

DANIELA STAICU

\begin{abstract}
REZUMAT
Characteristics of textile and clothing sector social entrepreneurs in the transition to the circular economy

The limits of the present take-make-waste business model are extremely visible when examining the textile and clothing industry. The concept of circular economy gained traction, which has led to the creation of policy actions throughout the life cycle of a product and at disposal. Transitioning from linear to circular economy business models requires significant value-chain changes in both production and consumption patterns. Existing circular business models are paving the way towards a paradigm shift. However, the literature has not retained much empirical evidence about these sustainabilityoriented innovators which are invisible and work in anonymity. This study provides a simple, yet rich and unique overview of the characteristics of circular economy business models in the textile and clothing sector in Romania, identified through qualitative analysis performed on the entire population of sustainability-oriented innovators identified in Romania in the textile and clothing sector in a previous study done by the same author. The data was collected using a structured questionnaire with 37 questions connected to four areas: human resources, legal and fiscal framework, customers and communication, and materials, tools or technology employed. With a $100 \%$ response rate, the real significance of this paper is that it may have discovered the real contribution of these agents of change in the circular economy, functional circular business models which have never been studied before as a population.
\end{abstract}

Keywords: circular economy, innovation, social enterprise, sustainability-oriented innovators, sustainable entrepreneurship, textile and clothing sector

Caracteristicile antreprenorilor sociali din sectorul textile și îmbrăcăminte în tranziția către economia circulară

Limitele prezentului model de afaceri preia-produce-consumă sunt extrem de vizibile când examinăm industria textilă și de îmbrăcăminte. Conceptul de economie circulară a câștigat tracțiune, ceea ce a condus la pollitici publice care vizează tot parcursul ciclului de viață al unui produs. Trecerea de la modelele de afaceri bazate pe liniaritatea resurselor folosite la modele circulare necesită modificări semnificative ale lanțului valoric atât în modelele de producție, cât și în cele de consum. Modelele circulare de afaceri existente deschid calea către o schimbare de paradigmă. Cu toate acestea, literatura de specialitate nu a reținut multe dovezi empirice despre acești inovatori orientați spre durabilitate, care sunt invizibili și funcționează în anonimat. Acest studiu oferă o imagine de ansamblu simplă, dar bogată și unică, a caracteristicilor modelelor de afaceri circulare din sectorul textil și de îmbrăcăminte din România, identificate prin analiză calitativă efectuată asupra întregii populații de inovatori orientați spre sustenabilitate identificați în România în domeniul textile și îmbrăcăminte într-un studiu anterior realizat de același autor. Datele prezentului studiu despre caracteristicile inovatorilor din domeniul textile și îmbrăcăminte au fost colectate folosind un chestionar structurat, cu 37 de întrebări legate de următoarele subiecte: resurse umane, cadru juridic și fiscal, clienți și comunicare, materiale, instrumente sau tehnologie utilizate. Cu o rată de răspuns de 100\%, importanța acestei cercetări este că prezintă contribuția reală a acestor agenți de schimbare în economia circulară, modele funcționale de afaceri circulare care nu au mai fost studiate până acum ca populație.

Cuvinte-cheie: economie circulară, inovare, întreprindere socială, inovatori orientați spre sustenabilitate, antreprenoriat durabil, sectorul textile și de îmbrăcăminte

\section{INTRODUCTION}

The transition to a circular economy is associated with circular businesses, models concerned with the sustainability of materials, processes, mainly sustainability of the value chain [1-3]. Despite the lack of circular strategies, existing business models are steadily shaping the textile and clothing sector. These innovators are contributing to the transition to the circular economy through incremental and transformational innovation. Studies about incremental business models [4-7] are already being discussed in the public space and studied by academia. Sustainability approaches to the textile and clothing sector are shifting from incremental to transformative business models, in an effort to engage in the transition to the circular economy innovations which produce accelerated change [8]. However, transformational innovation has not gained the same momentum, although these are offering real business models of applied circularity.

In Romania, a roadmap to circular economy has not yet been formulated despite of a variety of models 
available from other Member States, but a tentative proposal for a Circular Economic Strategy is being developed [9]. At this time, the literature related to Romanian circular business models is scarce and best practices in terms of circularity are absent. Most reports narrate about Romanian social entrepreneurs in general without a sectoral classification [10-11]. These innovators are practically invisible and no empirical data has been gathered to document their activities related to circularity. However, these models certainly exist since they appear mentioned in various reports. To summarize, these sustainable business models in the textile and clothing sector in Romania, with environmental and social sustainability in their core business [12] are invisible in the public discourse and their characteristics and achievements are not being promoted. The purpose of this research study was to explore the dimension of these sustainability-oriented innovators in the textile and clothing sector in Romania. To achieve the scope, the researcher identified the characteristics of the sustainability-oriented innovators in the textile and clothing sector by studying four areas related to the business model.

\section{LITERATURE REVIEW}

The transition towards a circular economy offers an opportunity to reduce Europe's environmental footprint through measures of diminishing raw material consumption and reducing waste generation [13-16]. In the past decade, the circular economy model has recently gained worldwide attention from business people, authorities and academia [2, 17, 18]. In the perspective of the urgent need for change, the circular business models are gaining traction, which has led to the creation of bi-directional policy actions: throughout the life cycle of a product and at disposal $[14,19,20,22]$. However, these policies cannot succeed if the business models are not aligning the value chain to the circularity principles. If designed properly for circularity, innovative business models could thrive and contribute to reducing the need for new products and raw materials as well as the efficient use of assets [23]. Textiles waste is relatively small in terms of weight as compared to other waste streams, but it has a large impact on human health and environment [24-27]. The limits of the present take-make-waste business model are extremely visible when examining the textile and clothing industry $[6,7,28]$. Transitioning from linear to circular economy business models is not simple and requires significant value-chain changes in both production and consumption patterns [29, 30]. The shift from a linear to a circular model in the textile and clothing sector is associated with the need to implement innovative business models, but the adoption of circular business strategies in the industry has been scarce [31-33, 9].

Thus, studies are being developed on the innovations in the field, the majority of them are dedicated to incremental innovators, companies dedicated for the mass-market [34]. However, only a few sustainable business models emerged from the population of sustainability-oriented innovators whose mission is environmentally and social driven, with insignificant value attributed to the profit [35-37]. These sustainability-oriented innovators are being recognized for their circular business models and best practices in the transition to the circular economy [8, 38, 39] Recent research $[40,41]$ identified the population of sustainable-oriented innovators in the textile and clothing sector in Romania: eleven social enterprises are pioneering circular economy. This is the population concerned by this study.

\section{METHODOLOGY}

In motivating the decision to use qualitative research, it is important provide a definition and to justify the use of qualitative research methodology. Creswell [42] defined qualitative research as a process of understanding based on different methodological traditions of inquiry that explore a social or human problem. According to Patton [43], through qualitative research methods, researchers produce a wealth of detailed data about a much smaller population. In this particular case, it is important to understand that the population being investigated qualifies for "a hard to reach" or "hard to capture" population [44] characterized by low numbers, members hard to identify, difficulty into identifying commonalities among the members, information about them rarely recorded and available for consultation, and not entirely known behaviour which leads to a poor choice of places or spaces in which to approach them [45].

The data was collected using a structured questionnaire, technique considered particularly useful when the sample size is relatively small [46-49]. It is important to mention that the researcher itself is an active participant in the field under investigation through its role of social entrepreneur in the field of clothing manufacturing at Atelier Merci, a social enterprise based in Bucharest, Romania. Based on prior literature review, the researcher defined the game-changers targeted by this research which are the object of previous research published by the author [40, 41]: small and medium-sized sustainability-oriented innovators, with a business model and mission aimed at contributing to diminishing environmental and social problems. Throughout this study the researcher employed four association of words to which assigned the same significance "game changer", "sustainability-oriented innovator", "social entrepreneur", "agent of change". Eleven Romanian sustainabilityoriented innovators were asked to participate in the survey: Made in Roșia Montană, Asociația D'Avent, Iuliana Pîslaru Design, Asociația Mai Bine - REDU, Mesteshukar ButiQ, Cup \& Candle, Upside Down, Crucea Roșie, Sector 6 - Bine Boutique, Asociația Viitor Plus - Atelierul de Pânză, Yard Sale, Asociația Merci Charity - Atelier Merci. The response rate was $100 \%$. The questions were designed by combining the findings resulted from previous work $[40,50]$ and 


\begin{tabular}{|c|c|c|c|}
\hline \multicolumn{4}{|c|}{ THE SECTIONS OF THE QUESTIONNAIRE } \\
\hline Section & Description & $\begin{array}{l}\text { Number of } \\
\text { questions } \\
\text { comprised }\end{array}$ & $\begin{array}{l}\text { Type of questions } \\
\text { (open-ended or } \\
\text { closed-ended) }\end{array}$ \\
\hline Profile of the social enterprise & $\begin{array}{l}\text { Legal form of the SE, year of creation, } \\
\text { number of employees, field of activity }\end{array}$ & 5 & $\begin{array}{l}\text { closed-ended and } \\
\text { open-ended }\end{array}$ \\
\hline $\begin{array}{l}\text { Current context in Romania for } \\
\text { developing a social business }\end{array}$ & $\begin{array}{l}\text { Perceptions on the conditions for starting } \\
\text { a SE in Romania, public policies, funding, } \\
\text { non-financial support, access to market, } \\
\text { workforce, consumers, awareness of SE. }\end{array}$ & 12 & closed-ended \\
\hline $\begin{array}{l}\text { Human resources in the social } \\
\text { enterprise }\end{array}$ & $\begin{array}{l}\text { Typology of the employees, skills required } \\
\text { at employment, difficulties in recruitment, } \\
\text { employee training }\end{array}$ & 9 & $\begin{array}{l}\text { closed-ended and } \\
\text { open-ended }\end{array}$ \\
\hline $\begin{array}{l}\text { Legal and fiscal measures for } \\
\text { the social enterprise }\end{array}$ & $\begin{array}{l}\text { Incentives for business development, } \\
\text { legislation related to social entrepreneurship }\end{array}$ & 5 & closed-ended \\
\hline $\begin{array}{l}\text { Customers and communication } \\
\text { of the social enterprise }\end{array}$ & $\begin{array}{l}\text { Typology of customers, collaboration with } \\
\text { other SE, marketing. }\end{array}$ & 7 & closed-ended \\
\hline $\begin{array}{l}\text { Raw materials and tools or } \\
\text { technology in the social enter- } \\
\text { prise }\end{array}$ & $\begin{array}{l}\text { Type of raw materials and procurement, } \\
\text { collaboration with textile plants, product } \\
\text { design, tools or technologies, barriers in } \\
\text { business development. }\end{array}$ & 11 & $\begin{array}{l}\text { closed-ended and } \\
\text { open-ended }\end{array}$ \\
\hline $\begin{array}{l}\text { Personal information about the } \\
\text { respondent }\end{array}$ & $\begin{array}{l}\text { Name, e-mail, age, gender, education, work } \\
\text { experience }\end{array}$ & 9 & $\begin{array}{l}\text { closed-ended and } \\
\text { open-ended }\end{array}$ \\
\hline
\end{tabular}

questionnaires from relevant national studies dedicated to social entrepreneurship developed. An email was sent to the SOI database [41] after the content was uploaded in the Google Forms platform for hosting surveys. The response rate was $100 \%$.

The questionnaire applied comprised thirty-seven questions structured into four areas under investigation: human resources, legal and fiscal framework, customers and communication, raw materials and tools or technology. Apart from these categories, the questionnaire comprised two other sections regarding the profile of the respondent and the profile of the social business (table 1). The questions were classified into three categories: open questions, openended questions, multiple choice questions. The answers were collected using a Web-based service entitled Google Forms and stored in the researcher's computer locked with a password.

Table 2

QUESTIONNAIRE SECTION: PROFILE OF THE SOCIAL ENTERPRISE

\begin{tabular}{|l|l|l|}
\hline $\begin{array}{l}\text { Questionnaire } \\
\text { section }\end{array}$ & \multicolumn{1}{|c|}{ Question } & Answer \\
\hline \multirow{4}{*}{$\begin{array}{l}\text { Social } \\
\text { business } \\
\text { profile }\end{array}$} & $\begin{array}{l}\text { The legal form of my } \\
\text { social business is: }\end{array}$ & Open question \\
\cline { 2 - 3 } & $\begin{array}{l}\text { The year of setting up } \\
\text { the social business is: }\end{array}$ & Open question \\
\cline { 2 - 3 } & Number of employees & Open question \\
\cline { 2 - 3 } & $\begin{array}{l}\text { What does the social } \\
\text { business do? }\end{array}$ & Open question \\
\cline { 2 - 4 } & $\begin{array}{l}\text { The social business is } \\
\text { focused on: }\end{array}$ & $\begin{array}{c}\text { 1. Production } \\
\text { 2. Services }\end{array}$ \\
\hline
\end{tabular}

The profile of the social enterprise is composed of the answers provided to thirty-seven questions divided into four sections: human resources, legal and fiscal measures for the social enterprise, customers and communication of the social enterprise, raw materials and tools or technology in the social enterprise (table 2).

\section{FINDINGS}

Previous research performed in 2019 employing traditional and virtual sampling research methods determined the population of sustainability-oriented innovators in the textile and clothing sector in the transition to the circular economy in Romania [41]. This population is the subject of analysis of this current research.

\section{Respondents' profile}

Most of the respondents to the questionnaire were founders and co-founders of the businesses with $36 \%$ of each of the two categories. $45 \%$ of them were aged 31 to 35 years old, followed by 26 to 30 years old representing $36 \%$. $83 \%$ of the respondents were female. Most respondents have a bachelor degree $(55 \%)$, followed by a master degree $(45 \%) .64 \%$ of the respondents have previous studies related to entrepreneurship. $73 \%$ of the respondents believe it would have been useful to pursue an entrepreneurship course before working in the social business. All the respondents have previous work experience. To summarize, the respondents are the creators of the social businesses analysed, majority females aged between 26 to 35 years old, with previous work 
experience and holding a bachelor or master degree, with previous studies related to entrepreneurship.

\section{The characteristics of the sustainability-oriented} innovators in the textile and clothing sector

\section{Business profile}

$54 \%$ of the SOI are dedicated to textile recycling (figure 1). Analysing the eleven SOI, based on Smits [51], business models advancing the T\&C sectors towards circularity, the Romanian SOI in the T\&C are based on the "circular" which by definition is a model of creating value from waste [51] and "sufficiency" models which by definition are models based on effective use of resources. The majority of the business models $(82 \%)$ are circular models of creating value from waste, followed by $73 \%$ of business models encouraging effective use of resources $73 \%$ of the SOI are dedicated to production.

$73 \%$ of the SOI respodents are dedicated to production (figure 2).

\section{Legal forms}

Four categories of legal forms resulted from the respondents' answers: Non-governmental organisation society with limited responsibility, Authorized person and Social Economy Structure (table 3).

\begin{tabular}{|c|c|c|}
\hline \multicolumn{3}{|c|}{$\begin{array}{l}\text { REGULATIONS RELATED TO THE LEGAL FORMS } \\
\text { ACCEPTED IN ROMANIA }\end{array}$} \\
\hline Legal form & Acronym & Regulated through \\
\hline $\begin{array}{l}\text { Non-governmental } \\
\text { organization }\end{array}$ & NGO & $\begin{array}{l}\text { Official Monitor - } \\
26 / 2000,2000\end{array}$ \\
\hline $\begin{array}{l}\text { Society with limited } \\
\text { responsibility }\end{array}$ & SRL & $\begin{array}{c}\text { Official Monitor - } \\
31 / 1990,1990\end{array}$ \\
\hline Authorized person & PFA & $\begin{array}{c}\text { Official Monitor - } \\
182 / 2006,2006\end{array}$ \\
\hline $\begin{array}{l}\text { Social Economy } \\
\text { Structure }\end{array}$ & SES & $\begin{array}{l}\text { Labour Ministry - } \\
219 / 2015,2015\end{array}$ \\
\hline
\end{tabular}

Most of the SOI were registered as societies with limited responsibility $(45 \%)$, followed by NGOs with $27 \%$. Only $9 \%$ of the SOI were registered as a structure of the social economy, structures developed especially for enterprises acting for the social greater good.

Longevity on the market

The population of the SOI questioned has 1-10 years' experience, with 2 of them having 7 years of experience. It is important to notice that these entities are active on the Romanian market in the last 10 years (starting 2009) though the law on social economy has been published only four years ago, in 2015.

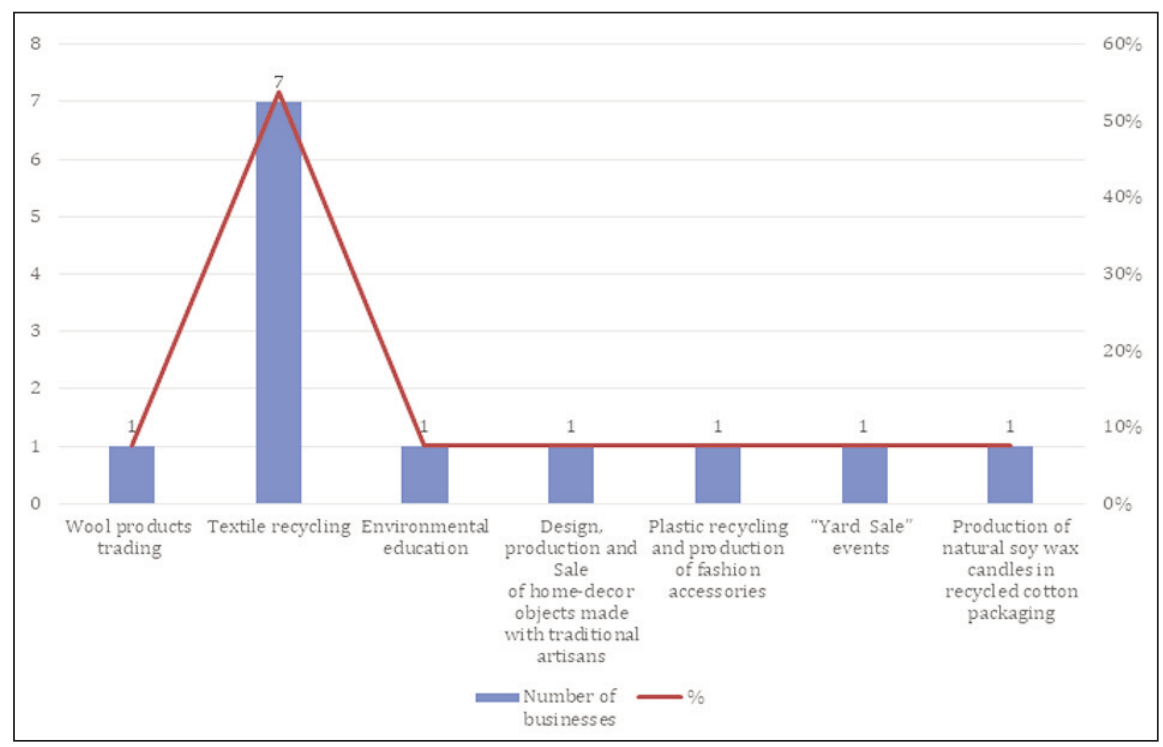

Fig. 1. Main activity of the SOI Human resources

All the eleven SOl employed 34 people, ranging from 1 to 12 employees. $90 \%$ of the employees of these SOI become productive within the first 90 days of starting a job (figure 4 and 5).

Most SOI hire unemployed people $(33 \%)$, followed by poor women, rural residents and people with disabilities (11\% of SOI for each of the three categories). We should not ignore the other categories of employees which were belonging to vulnerable populations, among them young

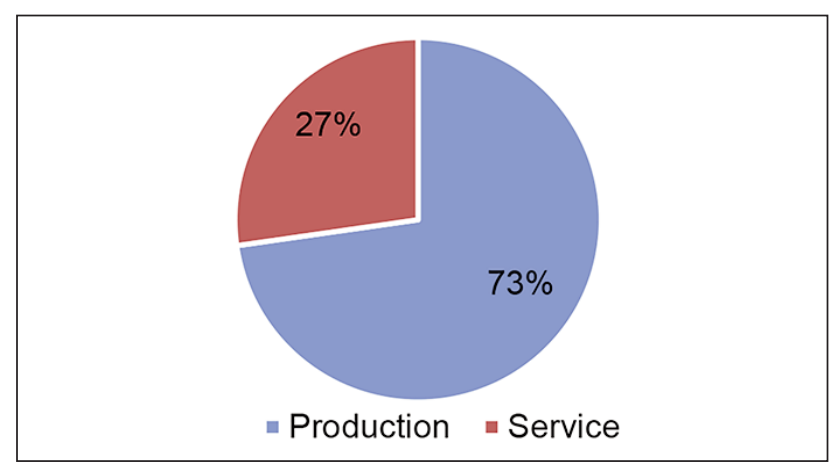

Fig. 2. Type of activity

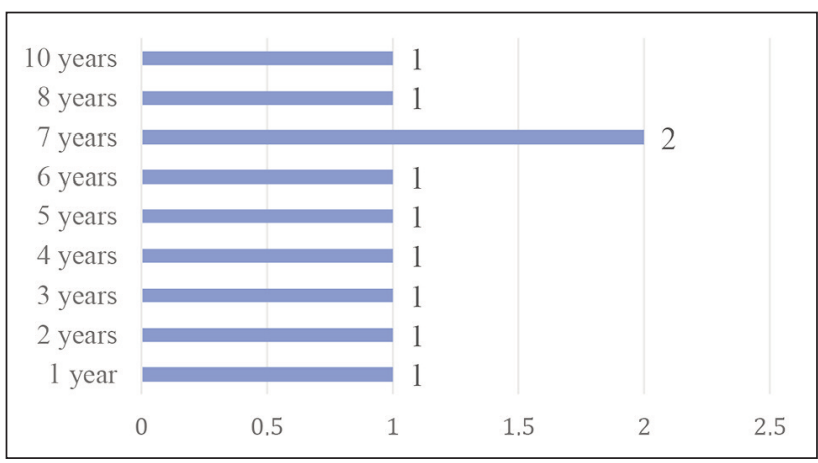

Fig. 3. SOI years of experience on the market 


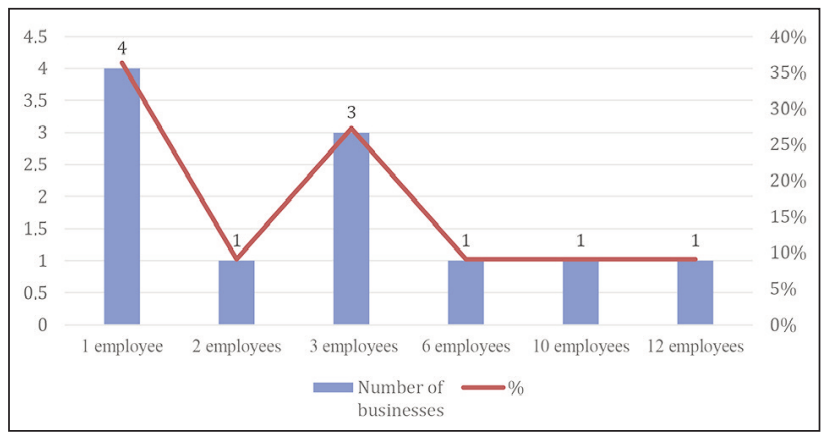

Fig. 4. SOI number of employees

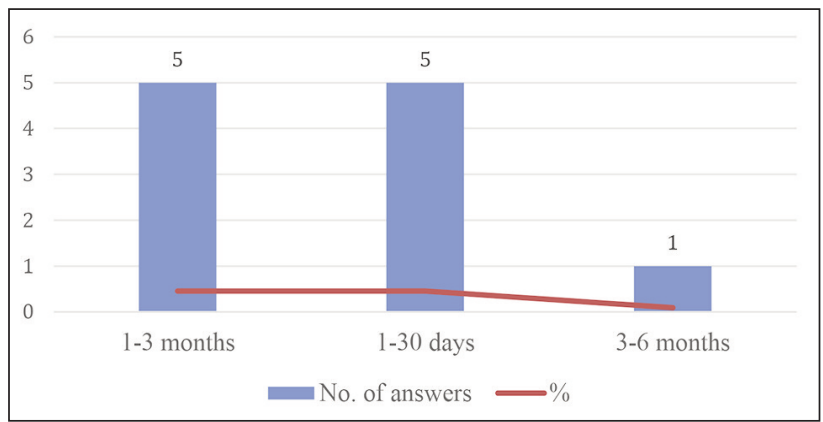

Fig. 5. Employee productivity timeline

people over 18 who are no longer included in the childless care system, Roma people in high-risk situations, women victims of domestic violence, monoparental families, young people and craftsmen. The answers to the question related to "Which skills are you searching for in future employees?" were collected and grouped into four main categories with $40 \%$ skills related to tailoring, and each of the following with $20 \%$ : skills related to knitting, skills related to product design and skills related to selling products/entrepreneurial spirit. One of the SOI mentioned that the skills related to product design are necessary because the products were purchased for utility and design. Moving to skills related to accountability, in equal percentages, the employer appreciates as being important: organizing abilities, meeting duties on time and being a team player. Third, the respondents highlighted mindset related skills searched in the future employees: the determination to keep a job (20\%) while the determination to learn is $80 \%$. The last categories of skills are related to personal values of the future employee, among these the most appreciated being cognitive flexibility $(27 \%)$, seriousness $(18 \%)$ and humanitarian values (18\%). The people employed show interest in getting a job (44\%), while only $25 \%$ have the qualification required.

Legal and fiscal framework

$55 \%$ of the respondents do not have knowledge about the social economy law 219/2015 provisions.
Customers, product and communication

Most customers are individuals (64\%) and it is important to signal that public institutions are not among the customers of SOI. The products of the SOI (figure 6 ) are purchased for design (32\%), followed by the mission of the social enterprise $(24 \%)$ and quality of the fabrics (20\%). $82 \%$ of the respondents already collaborate with other social businesses. $64 \%$ of the respondents intend to collaborate with other SOI. I

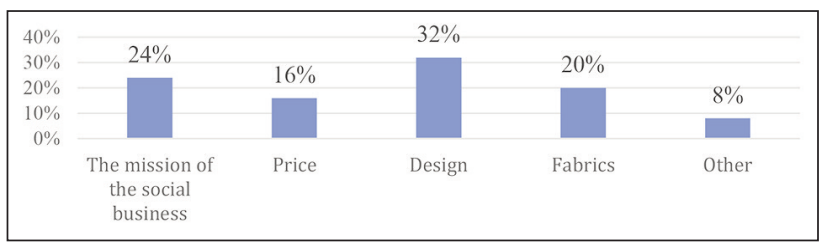

Fig. 6. The characteristics which determine the customers' purchase decision

$91 \%$ of the respondents intend to launch the business of the international market and the same percentage promote their products through a website and have been mentioned in the media.

Raw materials and technology

$42 \%$ of the raw materials employed are donated clothing, and only $8 \%$ recycled materials (figure 7 ).

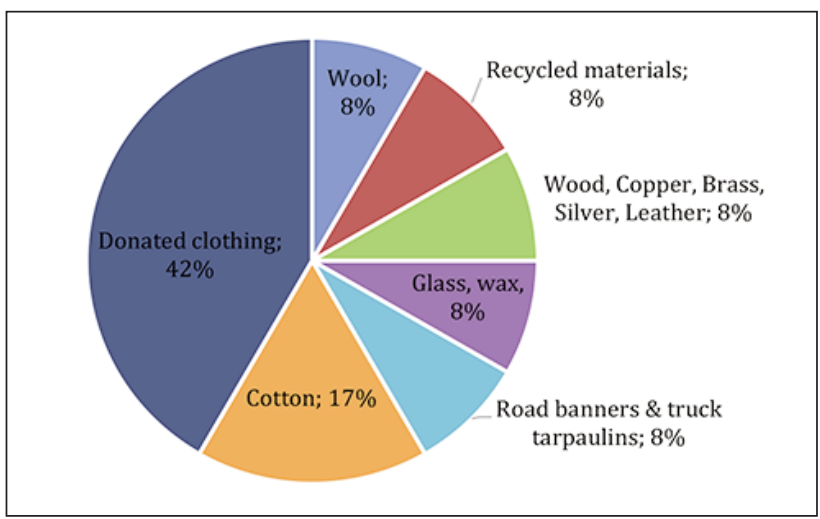

Fig. 7. Raw materials employed in the SOI questioned

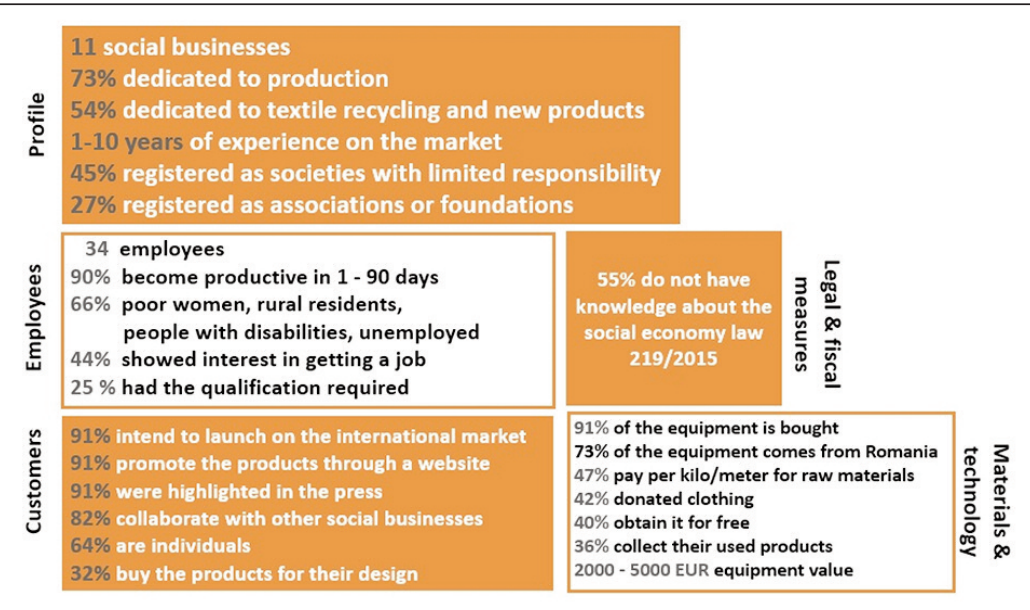

Fig. 8. A snapshot of the characteristics of sustainability-oriented innovators in the T\&C 
The sources of the raw materials $(36 \%)$ are various companies from Romania, followed by the textile stores and donations from individuals (36\%). $47 \%$ of the respondents pay per kilo or per meter for their raw material and $40 \%$ obtain it without paying. In equal percentage $(36 \%)$, the design is created in collaboration with a designer or by an employee. There is no collaboration with the Art University or students in the arts. $91 \%$ of the equipment is bought and $73 \%$ of it comes from Romania. The value of the equipment used is estimated between 2,000 and 5,000 EUR for $55 \%$ of the respondents. $64 \%$ of the respondents do not collect their used products from the customers as seen in figure 8 .

\section{CONCLUSIONS}

This is the first exercise of obtaining empirical data about the Romanian sustainability-oriented innovators in the textile and clothing sector and provides valuable information about the distribution and dimension of this category of circular economy stakeholders. The following characteristics were discussed: experience on the market, legal form, main activity, human resources, materials and technology, and customer typology. Although this study was designed to provide preliminary research into the characteristics of sustainability-oriented innovators in the textile and clothing sector in their transition to the circular economy, its real significance may be the discovery of the real impact of these agents of change in the circular economy.

To sum up, the interpretation of the results gave the following characteristics and contributions of the population of sustainability-oriented innovators in the textile and clothing in Romania: the majority of the innovators in the textile and clothing sector are circular models of creating value from waste, followed closely by business models encouraging effective use of resources being mostly dedicated to production and less to providing services. Most of the innovators were legally registered as societies with limited responsibility followed by NGO's.

The population questioned has 1 to 10 years' experience, and it is important to notice that these entities have been active on the Romanian market for 10 years (since 2009) even though the law on social economy has been published in 2015 . $90 \%$ of the employees become productive with the first 90 days of starting a job and most innovators hire unemployed people, followed by poor women, rural residents and people with disabilities.

Most of the characteristic skills related to these specific businesses were related to tailoring, followed by skills related to product design, sale of products and knitting in equal percentages. Next, moving to skills related to accountability, in equal percentages, the employer appreciates organizing abilities, meeting duties on time and being a team player. The last categories of skills are related to personal values of the future employee, among these the most appreciated being cognitive flexibility, seriousness and humanitarian values. $55 \%$ of the respondents indicated that they have no knowledge about the social economy law 219/2015 provisions.

Most customers are individuals, and it is important to signal that public institutions are not among these customers. The products are purchased for design, followed by the mission of the social enterprise, and quality of the fabrics. Most of the innovators already collaborate with other social businesses and intend to launch the business of the international market and promote their products through a website. The source of the raw materials are various companies from Romania, followed by the textile stores and donations from individuals. Less than half of the respondents pay per kilo or per meter for their raw material and $40 \%$ obtain it without paying. For a third, the design is created in collaboration with a designer or by an employee. There is no collaboration with the Art University or students in the arts. Most of the equipment is bought and three quarters is bought from Romania. The value of the equipment used is estimated between 2,000 and 5,000 Euro for more than half of the respondents. $64 \%$ of the respondents do not collect their used products from the customers.

Based upon the findings and the conclusions of the study, there are two decisively important implications for the circular economy ecosystem sectors. First, in order to facilitate the transition to circular business models, there are obvious barriers to transitioning to circular business models signalled by the low scores in some questions which have to be alleviated or best eliminated in order for the circular business models to develop. Second, the Romanian textile and clothing sector has functional business models and their activity is not being studied enough. Their characteristics can serve as best practices for the field of circular economy with the condition of being pulled from anonymity and invisibility, given a voice and placed at the table of discussion about the topic of circular economy. It is imperative for these circular business models to participate in all conversations about circularity and be inquired about the facilities, which would help these models scale up their businesses. So far, these circular business models have been only intrinsically motivated and it is the time for external stimulants.

\section{ACKNOWLEDGEMENTS}

This study is part of the doctoral thesis entitled "Models of Social Business in the Romanian Textile and Clothing Sector and Barriers in Business Development", author Dr. Daniela Staicu, coordinated by advisor and mentor, Prof. Univ. Dr. Carmen Păunescu (The Bucharest University of Economic Studies). I would like to acknowledge the support of the Bucharest University of Economic Studies, the Romanian-U.S. Fulbright Commission, and the Fulbright Program, for the opportunities offered during my doctoral studies. 


\section{REFERENCES}

[1] Pardo, R., Schweitzer, J.P., A long-term strategy for a European circular economy - setting the course for success, In: Policy Paper produced for the Think 2030 project, 2018, Brussels, Belgium

[2] Ellen MacArthur Foundation, A new textiles economy: Redesigning fashion's future, 2017, Available at: http://www.ellenmacarthurfoundation.org/publications [Accessed on June 2020]

[3] CSR Europe \& Universita Malta, Enablers and Barriers to a Circular Economy, 2018, Available at: www.csreurope.org/sites/default/files/uploads/LATEST_R2Pi\%20report_scroll\%20view\%20FINAL\%2007-082018.pdf [Accessed on June 2020]

[4] Sousa, T., Zomer, A., Magalhães, L., Zancul, E., Cauchick-Miguel, P.A., Exploring the challenges for circular business implementation in manufacturing companies: An empirical investigation of a pay-per-use service provider, In: Resources, Conservation and Recycling, 2018,135, 3-13

[5] Ballie, J., Woods, M., Circular by Design: A Model for Engaging Fashion/Textile SMEs with Strategies for Designed Reuse, In: Robert Crocker,Christopher Saint, Guanyi, 2018

[6] Jordão, C., Broega, A., Puppim, R, Marques, A.D., Sustainable entrepreneurship in the reuse of textile waste: $H$ Sarah Trading case study in Portugal, In: IOP Conference Series: Materials Science and Engineering, 2018, 459, 1

[7] Stål, H., Corvellec, H., A Decoupling perspective on Circular Business Model implementation: illustrations from Swedish apparel, In: Journal of Cleaner Production, 2017,171

[8] Gardetti, M.A., Muthu, S.S., Sustainable apparel? Is the innovation in the business model? The case of the IOU Project, In: Textile and clothing sustainability Journal, 2015, 1, https://doi.org/10.1186/s40689-015-0003-0

[9] The Institute for Research in Circular Economy and Environment, Presentation of the activity, 2018, Available at: https://www.ircem.ro/about-us/history/ [Accessed on June 2020]

[10] Damaschin-T,ecu, R., Etchart, N., Building the Social Investment Industry in Central and Eastern Europe, 2016, Available at: https://nesst.squarespace.com/s/2016-RO-BIdg-Social-Investment-Industry-ENG-FINAL-web.pdf [Accessed on June 2020]

[11] Ashoka, C.A. Foundation, Fabric of change. Social entrepreneurs' transforming the apparel industry, 2016, Available at: http://bit.ly/focreportpdf [Accessed on June 2020]

[12] Păunescu, C., Pascu, A.I., Pop, O., Social Enterprise: How does this Way of doing Business differ from other Forms of Enterprise, In: Quality. Access to Success Scientific Journal of Management Systems, 2016, 17, 153, 108-110, ISSN 1582-2559

[13] The European Commission, Communication from the Commission to the European Parliament, The Council, The European Economic and Social Committee and the Committee of the Regions on Closing the loop, 2015, Available at: www.eea.europa.eu/policy-documents/com-2015-0614-final [Accessed on June 2020]

[14] The European Commission, Circular Economy: New rules will make EU the global front-runner in waste management and recycling, 2018, Available at: http://europa.eu/rapid/press-release_IP-18-3846_en.htm [Accessed on June 2020]

[15] The Council, The European Economic and Social Committee and the Committee of the Regions on the implementation of the Circular Economy Action Plan, 2017, Available at: https://ec.europa.eu/chafea/agri/ content/report [Accessed on June 2020]

[16] Whicher A., Harris C., Beverley, K., Swiatek, P., Design for circular economy: Developing an action plan for Scotland, In: Journal of Cleaner Production, 2017, 1-12

[17] Henninger, C.E., Ryding, D., Alevizou, P.J., Goworek, H., Sustainability in Fashion, Palgrave Macmillan, 2017

[18] Scheffer, M.R., In-depth assessment of the situation of the T\&C sector in the EU and prospects, 2012, Available at: https://ec.europa.eu/docsroom/documents/10482/attachments/1/translations/en/renditions/native [Accessed on June 2020]

[19] The European Commission, Report from the Commission to the European Parliament, The Council, The European Economic and Social Committee and the Committee of the Regions on the implementation of the Circular Economy Action Plan, 2017, Available at: https://ec.europa.eu/chafea/agri/content/report [Accessed on June 2020]

[20] Resta, B., Gaiardelli, P., Pinto, R., Dotti, S., Enhancing environmental management in the textile sector: An organisational-life cycle assessment approach, In: Journal of Cleaner Production, 2016, 135, 620-632

[21] Farrant, L., Olsen, S.I., Wangel, A., Environmental benefits from reusing clothes, In: International Journal Life Cycle Assess, 2010, 15, 726-736

[22] Seuring, S., Müller, M., From a literature review to a conceptual framework for sustainable supply chain management, In: Journal of Cleaner Production, 2008, 16, 1699-1710

[23] Gardetti, M.A., Torres, A.L., Sustainable in fashion and textiles: Values, design, production and consumption, Greenleaf Publishing Limited, 2013

[24] Sandin, G., Peters, G.M., Environmental impact of textile reuse and recycling - A Review, In: Journal of Cleaner Production, 2018, 184, 353-365.

[25] Koszewska, M., Circular Economy - Challenges for the Textile and Clothing Industry, In: Autex Research Journal, 2018, 18, 4, 337-347

[26] James, K., Lings J., Life Cycle Management and Circular Economy Challenges for the Textile Sector: Session Wrap Up. In: Benetto E., Gericke K., Guiton M. (Eds.) Designing Sustainable Technologies, Products and Policies. Springer, 2018

[27] Stengg, W., The textile and clothing industry in the EU - A survey, 2001, Available at: https://ec.europa.eu/ docsroom/documents/2958/attachments/1/translations/en/renditions/pdf [Accessed on June 2020] 
[28] Van Ewijk, S., Stegemann, J.A., Limitations of the waste hierarchy for achieving absolute reductions in material throughput, In: Journal of Cleaner Production, 2016, 132, 122-128

[29] Ghisellini, P., Cialani, C., Ulgiati, S., A review on circular economy: the expected transition to a balanced interplay of environmental and economic systems, In: Journal of Cleaner Production, 2016, 114: 11-32

[30] Burns, L., Tackling textile waste, 2016, Available at: http://www.responsibleglobalfashion.com/blog/2016/7/tacklingtextile-waste [Accessed on June 2020]

[31] Thorisdottir, T.S., Johannsdottir, L., Sustainability within Fashion Business Models: A Systematic Literature Review, In: Sustainability, 2019,11, 8

[32] Fraccascia, L., Giannoccaro, I., Agarwal, A., Hansen, E., Business models for the circular economy: Opportunities and challenges, In: Business Strategy and the Environment, 2019, 1, 430-432

[33] Hall, J., Daneke, A.G., Lenox, M., Sustainable development and entrepreneurship: Past contributions and future directions, In: Journal of Business Venturing, 2010, 25, 439-448

[34] Sandybayev, A., Competing in Volatile Markets through Analysis of Agile Supply Chain. Case of H\&M, In: Journal of Human and Social Science Research, 2015, 6, 59-66

[35] Stratan, D., Success factors of sustainable social enterprises through circular economy perspective, In: Visegrad Journal on Bioeconomy and Sustainable Development, 2017, 1:17-23, https://doi.org/10.1515/vjbsd-2017-0003

[36] Martin, M., Making Impact Investible, In: Impact Economy Working Papers, 2013, 4

[37] Cohen, B., Winn, M.I., Market imperfections, opportunity and sustainable entrepreneurship, In: Journal of Business Venturing, 2007, 22, 1, 29-49

[38] Franco, M., Circular economy at the micro level: A dynamic view of incumbents' struggles and challenges in the textile industry, In: Journal of Cleaner Production, 2017, 68

[39] Hansen, E. G., Grosse-Dunker, F., Sustainability-Oriented Innovation, In: Encyclopedia of Corporate Social Responsibility Heidelberg, New York: Springer-Verlag, 2013, 2407-2417, https://doi.org/10.1007/978-3-642-28036-8

[40] Staicu, D., Pop, O., Mapping the interactions between the stakeholders of the circular economy ecosystem applied to the textile and apparel sector in Romania, In: The management and marketing journal, 2019, 13, 1190-1209

[41] Staicu, D., Identifying circular business models through traditional and snowball sampling, In: The International Conference on Business Excellence 2020, Conference proceedings, 2020

[42] Creswell, J. W., Qualitative inquiry and research design: Choosing among five traditions, Thousand Oaks, CA, US: Sage Publications, Inc, 1998

[43] Patton, M. Q., Qualitative evaluation and research methods (2nd ed.), Thousand Oaks, CA, US: Sage Publications, Inc, 1990

[44] Baltar, F., Brunet, I., Social research 2.0: virtual snowball sampling method using Facebook, In: Internet Research, 2012, 22, 1, 57-74

[45] Marpsat, M., Razafindratsima, N., Survey Methods for Hard-to-Reach Populations: Introduction to the Special Issue, In: Methodological Innovations Online, 2010, 5, 2, 3-16, https://doi.org/10.4256/mio.2010.0014

[46] Drever, E., Using semi-structured interviews in small-scale research. A teacher's Guide, Edinburgh: Scottish Council for Research in Education, 1995

[47] Pathak, A., Intratat, C., Use of Semi-Structured Interviews to Investigate Teacher Perceptions of Student Collaboration, In: Malaysian Journal of ELT Research, 2012, 8, 1

[48] Alvarez, R., Urla, J., Tell me a good story: Using narrative analysis to examine information requirements interviews during an ERP implementation, In: The DATABASE for Advances in information Systems, 2002, 33, 1, 38-52

[49] Horton, J., Macve R., Struyven. G., Qualitative research: Experiences in using semi structured interviews, In: C. Humphrey \& B. Lee (Eds.). The real life guide to accounting research: A behind-the-scenes view of using qualitative research methods, London: Elsevier, 2004

[50] Osterwalder, A. Pigneur, Y., Business Model Generation. A Handbook for visionaries, game changers and challengers, New Jersey: John Wiley \& Sons. Inc, 2010

[51] Smits, H., Service-based business models and circular strategies for textiles, 2015, Available at: http://www. resyntex.eu/images/downloads/ValrieJBoiten_Textile_collection_strategies.pdf [Accessed on June 2020]

\section{Author: \\ DANIELA STAICU}

The Bucharest University of Economic Studies, Doctoral School of Business Administration, Room 1407, building Mihai Eminescu, B-dul Dacia, no. 41, District 1, 010404, Bucharest, Romania

\section{Corresponding author:}

DANIELA STAICU

e-mail: daniela.staicu@fabiz.ase.ro 